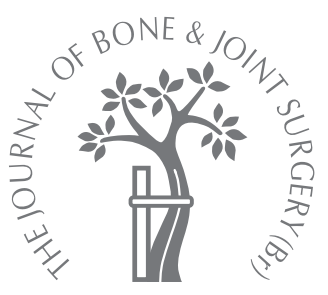

G. L. Cribb,

S. C. S. Loo,

I. Dickinson

From The Wesley and

Princess Alexandra

Hospitals, Brisbane, Australia

In. L. Cribb, MBChB, MRCS, FRCS(Trauma \& Orth),

Consultant Orthopaedic

Surgeon

Robert Jones and Agnes Hunt

Orthopaedic Hospital,

Oswestry SY10 7AG, UK.

S. C. S. Loo, BSc, MBBS, Orthopaedic Registrar

Princess Alexandra Hospital

199 Ipswich Road,

Woolloongabba, Brisbane,

Queensland, Australia 4102.

I. Iickinson, MBBS, FRACS,

FAOrthA, Consultant

Orthopaedic Surgeon

The Wesley Hospital,

Coronation Drive, Brisbane,

Queensland, Australia 4066

Correspondence should be sent to Miss G. L. Cribb; e-mail:

gilliancribb@me.com

(C)2010 British Editorial Society

of Bone and Joint Surgery

doi:10.1302/0301-620X.92B3

$22331 \$ 2.00$

$J$ Bone Joint Surg [Br] 2010;92-B:424-9.

Received 20 January 2009;

Accepted after revision 19

November 2009

\title{
Limb salvage for soft-tissue sarcomas of the foot and ankle
}

We evaluated the oncological and functional outcome of 27 patients who had limb salvage for a soft-tissue sarcoma of the foot or ankle between 1992 and 2007, with a mean follow-up of 7.5 years (1.05 to 16.2 ). There were 12 men and 15 women, with a mean age at presentation of 47 years (12 to 84). Referrals came from other hospitals for 16 patients who had previous biopsy or unplanned excision, and 11 presented de novo. There were 18 tumours located in the foot and nine around the ankle. Synovial sarcoma was the most frequent histological diagnosis. Excision was performed in all cases, with 16 patients requiring plastic surgical reconstruction with 13 free and three local flaps. Adjuvant treatment was undertaken in 20 patients, 18 with radiotherapy and two by chemotherapy. Limb salvage was successful in 26 of the 27 patients. There have been two local recurrences and two mesenchymal metastases. Four patients have died of their sarcoma and two of other causes.

Function was evaluated with the Toronto Extremity Salvage Score and a mean overall score of 89.40 (52.1 to 100) was obtained. A questionnaire revealed that all surviving patients are able to wear normal shoes and none require a walking aid.

Limb salvage can achieve good oncological and functional results with additional treatment.

Soft-tissue tumours of the foot and ankle are relatively common, but few are malignant. Soft-tissue sarcomas account for $0.63 \%$ of all new cases and $1.15 \%$ of deaths from cancer in the United States. Fewer than $10 \%$ of all softtissue sarcomas arise in the foot and ankle. ${ }^{1,2}$ The presence of a sarcoma in the lower limb has been an indication for amputation but in the 1970 s and 1980 s the combination of conservative surgery and adjuvant radiotherapy made limb salvage more feasible. ${ }^{3-5}$

It was not until the $1990 \mathrm{~s}$ that this approach, combined with plastic surgical reconstruction, was used for soft-tissue sarcomas of the distal part of the limb. ${ }^{6-10}$ Adjuvant radiotherapy can be administered before or after surgery as an external beam or by brachytherapy. External beam techniques are most commonly used. Brachytherapy can be supplemented by external beam radiotherapy, but can also be used as the only form of adjuvant treatment. ${ }^{11}$ Brachytherapy involves the placement of after-loading catheters into the tumour bed during the operation (Fig. 1). The catheters are loaded in the days after surgery and then eventually removed. This is a very accurate technique, as the bed of the tumour is under direct vision when the catheters are positioned, and it is generally well tolerated. Catheters can be placed adjacent to free flaps and the periosteum.

Few series have specifically reviewed the management of soft-tissue sarcomas of the foot and ankle. ${ }^{7,8,10}$ The aim of this study was to examine the treatment and functional outcome of soft-tissue sarcomas of the foot and ankle at our regional orthopaedic oncology unit.

\section{Patients and Methods}

Between 1992 and 2007, 29 patients presented to our unit with a soft-tissue sarcoma of the foot or ankle. Two patients, seen in 1993 and 1996, had a primary amputation, as at that time preservation of the distal part of the limb was not thought to be possible. Limb salvage was undertaken in 27 patients, and these formed our study group. Amputation was offered as an alternative to the patients who required plastic surgical reconstruction, but none opted for this.

We traced patients from the Queensland Tumour Database and reviewed our medical records. An attempt was made to contact all surviving patients to obtain information from a 


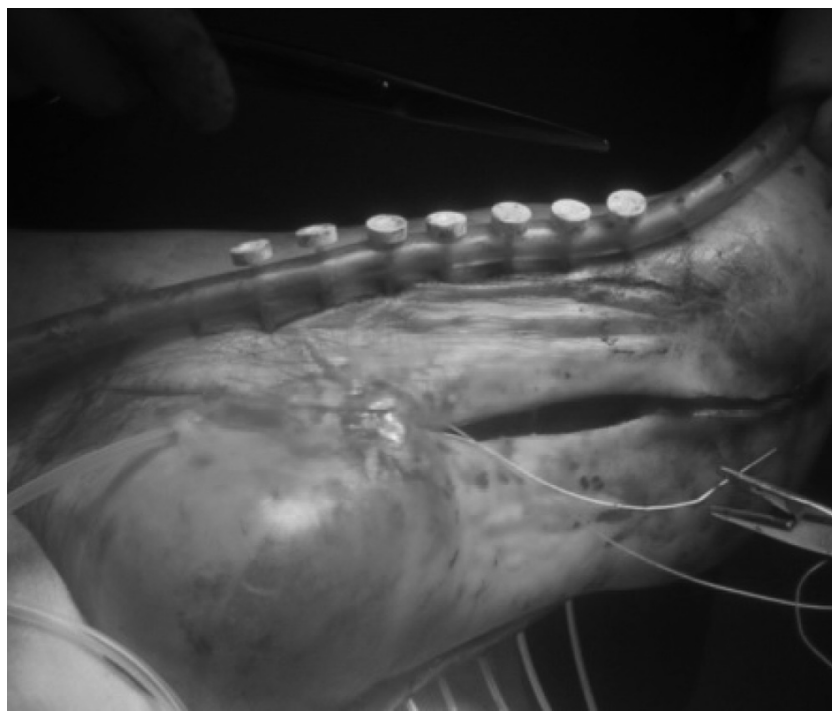

Fig. 1

Brachytherapy catheters in situ prior to closure of the skin.

questionnaire assessing their current symptoms, occupation, ability to participate in sports/hobbies, footwear, cosmesis and satisfaction with the treatment. Function was evaluated with the Toronto Extremity Salvage Score (TESS). ${ }^{12}$ The dates and cause of death of the non-survivors was obtained from the Queensland Cancer Registry at The Cancer Council, Queensland, Australia.

\section{Results}

There were 12 men and 15 women, with a mean age at presentation of 47 years (12 to 84), In 16 patients an unplanned excision or biopsy had been carried out prior to referral to our unit; 11 presented primarily. MR scans were performed on all patients, including those who had previous surgery, to image the lesion locally, and a CT scan of the chest was used for distant staging at the time of diagnosis. The mean follow-up was for 7.5 years (1.05 to 16.2) (Table I).

Characteristics of the tumours. Nine were located around the ankle and 18 in the foot. Of those in the foot, seven were on the plantar aspect (Fig. 2), four on the dorsum and three on the medial foot, two each in the hindfoot and big toe. Where the patient presented de novo, an open biopsy was performed with an intra-operative frozen section to establish the diagnosis. There were 12 patients with a synovial sarcoma, which was the most common histological subtype (Table I).

Details of treatment. This depended on any previous treatment, the location of the tumour and the histological subtype, and was formulated with close liaison between all members of the multidisciplinary team.

All were fully informed about the options for treatment and the potential complications. Those requiring plastic surgical reconstruction and/or radiotherapy were seen by the appropriate specialist before operation.
All had a wide excision of their tumour or a wider excision of a lesion which had previously been excised inadequately. Plastic surgical reconstruction was required in 16 patients, with 13 having a free flap and three requiring local flaps. Of the free flaps, there were ten from the radial aspect of the forearm (Fig. 3), one from the latissimus dorsi and two from the gracilis (Table II).

One patient had a positive margin after excision. A further excision was performed with an intra-operative frozen section and skin grafting to the bed, which was adjacent to a radial forearm flap. Otherwise all other surgical margins were clear of tumour, although in many cases they were very close.

Adjuvant oncological treatment is summarised in Table I. In general, where a patient presented de novo, external beam radiotherapy was performed before operation. If there had been a previous inadequate excision, external beam radiotherapy was carried out after operation, four cases also had brachytherapy. Two patients had chemotherapy as part of their primary treatment. One with a synovial sarcoma had pre-operative chemotherapy, and another with a rhabdomyosarcoma had chemotherapy before and after operation. No adjuvant treatment was used in seven patients.

Post-operative complications (Table II). There was one major wound complication in patient 18 who initially had an intralesional excision of a high-grade myxofibrosarcoma of the lateral aspect of the ankle at another institution. We carried out a wider excision with reconstruction using a radial forearm flap and external beam radiation after operation. An area of the flap failed to heal, became ulcerated, and subsequently resulted in a painful, swollen non-functional limb. After 22 months a below-knee amputation was needed. This was the only failure of a flap, giving an overall survival rate of flaps of $94 \%$ (15 of 16) and of the free flaps $92 \%$ (12 of 13 ).

Superficial skin problems occurred in four patients following post-operative radiotherapy. In two who had a free flap, brachytherapy and external beam radiotherapy after operation had delayed wound healing. One patient who had pre-operative radiotherapy developed necrosis of the wound edge which required excision of these areas, and a further patient who had not had any adjunctive treatment had delayed wound healing. A patient aged 72 with multiple medical comorbidities suffered a small post-operative cerebrovascular event.

Oncological outcome. Follow-up data were available for 26 of the 27 patients (Table I). Patient 19 was followed for 13 months after surgery but has since been lost to followup, although data from the Queensland Cancer Council indicate that she is still alive. Deaths from the sarcoma occurred in four patients $(13.8 \%)$. All had pulmonary disease, and two also had extrapulmonary metastases. A further two patients have died of other causes. The mean time from operation to death from the sarcoma was 4.68 years (1.05 to 7.71$)$. 
Table I. Histology, adjuvant therapy, current status and Toronto extremity salvage score (TESS)

\begin{tabular}{|c|c|c|c|c|c|c|}
\hline Patient & $\begin{array}{l}\text { Age at presentation } \\
\text { (yrs) }\end{array}$ & Diagnosis & Adjuvant therapy ${ }^{*}$ & $\begin{array}{l}\text { Current disease } \\
\text { status }^{\dagger}\end{array}$ & $\begin{array}{l}\text { Duration of } \\
\text { follow-up (yrs) }\end{array}$ & TESS \\
\hline 1 & 44 & Synovial sarcoma & Post-operative RT 60 Gy 30 fractions & DFS & 3.95 & 100.00 \\
\hline 2 & 15 & Synovial sarcoma & Post-operative RT 50 Gy 25 fractions & DFS & 3.57 & 75.00 \\
\hline 3 & 40 & Synovial sarcoma & $\begin{array}{l}\text { Brachy } 7 \text { catheters } 1050 \text { Gy } 3 \text { fractions } \\
\text { Post-operative } 50 \text { Gy } 25 \text { fractions }\end{array}$ & Thigh met (excised) & 6.08 & 52.08 \\
\hline 4 & 21 & Synovial sarcoma & None & DFS & 8.28 & 100.00 \\
\hline 5 & 48 & Synovial sarcoma & Pre-operative RT 50 Gy 25 fractions & DFS & 16.20 & 100.00 \\
\hline 6 & 12 & Synovial sarcoma & $\begin{array}{l}\text { Pre-operative RT } 50 \text { Gy fractions } \\
\text { Post-operative } 10 \mathrm{~Gy} 5 \text { fractions }\end{array}$ & DFS & 9.02 & 82.26 \\
\hline 7 & 65 & Synovial sarcoma & $\begin{array}{l}\text { Brachy } 7 \text { catheters } 800 \text { cGy } 4 \text { fractions } \\
\text { Post-operative } 50 \text { Gy } 28 \text { fractions }\end{array}$ & DFS & 12.23 & 95.54 \\
\hline 8 & 44 & Synovial sarcoma & $\begin{array}{l}\text { Brachy } 7 \text { catheters } 1050 \text { cGy } 3 \text { fractions } \\
\text { Post-operative } 50 \text { Gy } 25 \text { fractions }\end{array}$ & DFS & 6.04 & 84.62 \\
\hline 9 & 22 & Synovial sarcoma & Post-operative RT 65 Gy 35 fractions & DFS & 6.56 & - \\
\hline 10 & 61 & Synovial sarcoma & $\begin{array}{l}\text { Brachy } 7 \text { catheters } 1050 \text { cGy } 3 \text { fractions } \\
\text { Post-operative } 50 \text { Gy } 25 \text { fractions }\end{array}$ & $\begin{array}{l}\text { DoD (pulmonary } \\
\text { disease) }\end{array}$ & - & - \\
\hline 11 & 57 & Synovial sarcoma & Pre-operative chemotherapy & $\begin{array}{l}\text { DoD (pulmonary and } \\
\text { extra pulmonary } \\
\text { disease) }\end{array}$ & - & - \\
\hline 12 & 47 & Synovial sarcoma & $\begin{array}{l}\text { Brachy } 8 \text { catheters } 1050 \text { cGy } 3 \text { fractions } \\
\text { Post-operative } 44 \text { Gy } 22 \text { fractions }\end{array}$ & $\begin{array}{l}\text { LR, DoD (pulmonary } \\
\text { disease) }\end{array}$ & - & - \\
\hline 13 & 35 & Clear cell sarcoma & Post-operative RT 60 Gy 35 fractions & DFS & 1.05 & 97.58 \\
\hline 14 & 36 & Clear cell sarcoma & None & DFS & 15.39 & - \\
\hline 15 & 22 & Clear cell sarcoma & $\begin{array}{l}\text { Brachy } 3 \text { catheters } 20 \mathrm{~Gy} \\
\text { Post-operative } 50 \mathrm{~Gy} 27 \text { fractions }\end{array}$ & DFS & 10.73 & 100.00 \\
\hline 16 & 61 & Myxofibrosarcoma & Pre-operative RT 60 Gy 30 fractions & DFS & 2.74 & 90.18 \\
\hline 17 & 84 & Myxofibrosarcoma & Post-operative RT 50 Gy 25 fractions & DFS & 2.02 & 71.75 \\
\hline 18 & 60 & Myxofibrosarcoma & $\begin{array}{l}\text { Post-operative RT } 50 \text { Gy } 25 \text { fractions, } \\
14 \text { Gy } 7 \text { fractions }\end{array}$ & DFS & 6.71 & $\mathrm{BKA}^{\ddagger}$ \\
\hline 19 & 62 & $\begin{array}{l}\text { Malignant fibrous } \\
\text { histiocytoma }\end{array}$ & None & Lost to follow-up & - & - \\
\hline 20 & 72 & $\begin{array}{l}\text { Malignant fibrous } \\
\text { histiocytoma }\end{array}$ & Pre-operative RT 60 Gy 30 fractions & D other D & - & - \\
\hline 21 & 37 & $\begin{array}{l}\text { Spindle cell liposar- } \\
\text { coma }\end{array}$ & None & DFS & 4.42 & 100.00 \\
\hline 22 & 61 & Eptheliod sarcoma & None & DFS & 4.65 & 84.62 \\
\hline 23 & 15 & $\begin{array}{l}\text { Alveolar } \\
\text { rhabdomysarcoma }\end{array}$ & Pre- and post-operative chemotherapy & DFS & 8.60 & 100.00 \\
\hline 24 & 54 & $\begin{array}{l}\text { Acral myxoinflamma- } \\
\text { tory sarcoma }\end{array}$ & -None & LR (excised) & 4.14 & 67.74 \\
\hline 25 & 56 & $\begin{array}{l}\text { Dermatofibrosar- } \\
\text { coma }\end{array}$ & None & DFS & 14.45 & 100.00 \\
\hline 26 & 60 & $\begin{array}{l}\text { Pleomorphic sar- } \\
\text { coma }\end{array}$ & $\begin{array}{l}\text { Pre-operative RT } 50 \text { Gy } 25 \text { fractions, } \\
10 \text { Gy } 5 \text { fractions }\end{array}$ & $\begin{array}{l}\text { DoD (pulmonary and } \\
\text { extra pulmonary } \\
\text { disease) }\end{array}$ & - & - \\
\hline 27 & 75 & Leiyomyosarcoma & Post-operative RT 50 Gy 25 fractions & D other D & - & - \\
\hline
\end{tabular}

* RT, radiotherapy; brachy, brachytherapy

† DFS, disease-free survival; DoD, died of disease; D other D, died of other disease; LR, local recurrence

‡ BKA, below-knee amputation

The Kaplan-Meier analysis for overall survival is shown in Figure 4 and the disease-specific survival in Figure 5.

There have been two local recurrences. This developed in the first (patient 24) 29 months after re-excision of the positive margin for the acral myxoinflammatoryfibroblastic sarcoma. Treatment was by a further excision and a second reconstruction using a radial forearm flap. Histological examination revealed that the recurrence was of a highgrade spindle cell malignant sarcoma and external beam radiation was given, $60 \mathrm{~Gy}$ in 30 fractions after operation.

The second local recurrence (patient 12) was of a hindfoot synovial sarcoma, which had initially had an unplanned intralesional excision at the referring centre.
The patient then underwent a wider excision with radial forearm flap and a combination of brachytherapy and external beam radiation. The local recurrence developed after 32 months when the patient returned to the United States, where she was a citizen, to continue her treatment. She ultimately died of the disease.

There have been two ipsilateral limb metastases. Patient 26 developed a lesion in the mid-thigh from a high-grade pleomorphic sarcoma which subsequently also metastasised to the lungs and axilla. The patient has now died of his disease. A further patient (patient 3 ) developed a recurrence in the groin, which has been excised. In order to achieve a clear margin a vascular resection and soft-tissue reconstruc- 


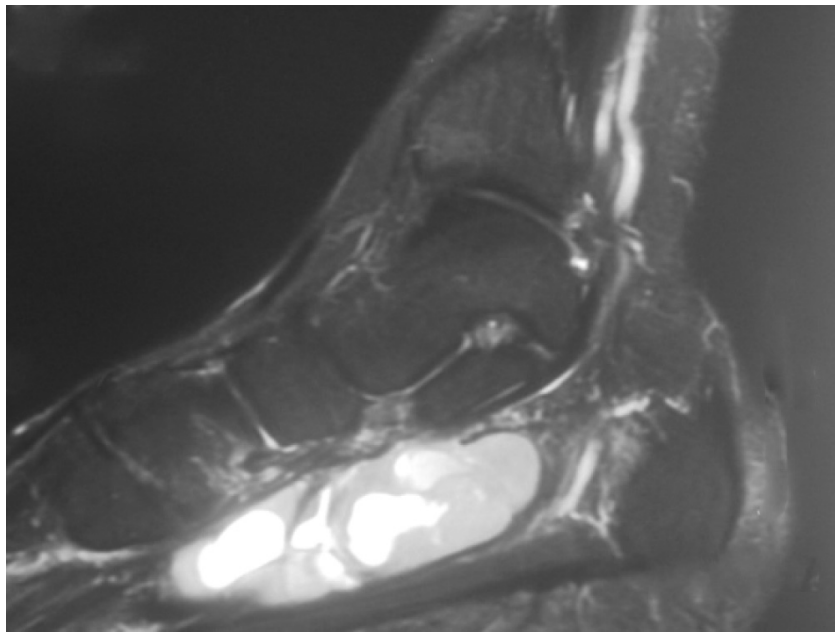

Fig. 2

MR scan of a synovial sarcoma on the plantar aspect of the foot.
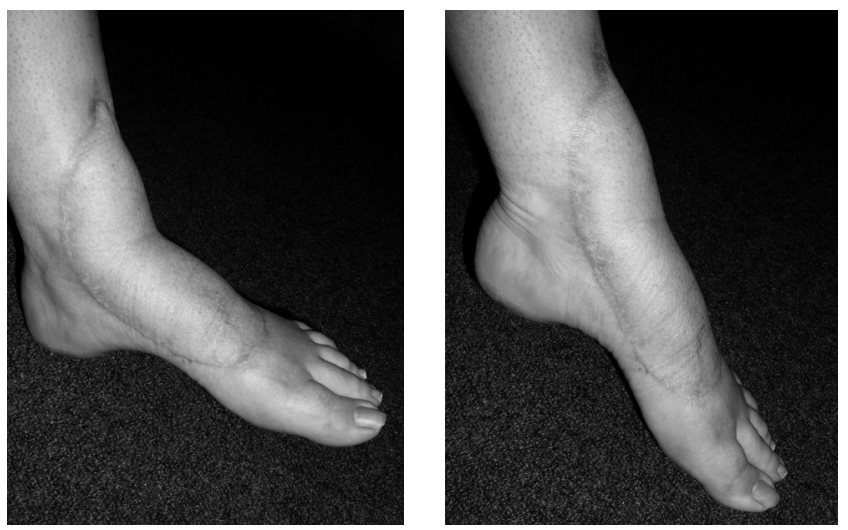

Fig. 3a

Fig. 3b

a) Radial forearm flap three years after operation. b) Maximum plantar flexion in the patient in $3 a$.

tion with a transverse rectus abdominis myocutaneous flap was performed. The patient subsequently had external beam radiation to this area, complicated by an infection of the wound which responded to intravenous antibiotics.

Functional scores. We were able to contact 17 of the surviving patients, and so TESS scores were available for only 17 of the 21 survivors. The mean score was 89.4 (52.08 to $100)$, with the maximum possible score being 100 . There was marked variation in the scores. A low score (52.1) was seen in the patient who has recently had a major reconstruction for recurrence in the groin. Low scores were also seen in the patient with a local recurrence who required a second radial forearm flap (52.1), in a woman aged 86 with degenerative disease in several other joints (71.1) and in a man who had previously had surgery on his ipsilateral hip and ankle following a road traffic accident (84.6). Of the four patients whose scores were assessed, one had required a below-knee amputation for failed limb salvage, and one has been lost to follow-up. The other two could not be contacted at the time of the study, but both were functioning well at their last follow-up.

The mean TESS score for the patients who had plastic surgical reconstruction was 85.6 (52.1 to 100), and for those without, 96.3 (82.3 to 100). This was not significant using the Mann-Whitney U test.

The mean TESS score for patients who presented to our unit de novo was 91.4 (82.3 to 100) and 87.0 (52.1 to 100) for those who had prior surgery at another institution. This was not significant using the Mann Whitney U test.

Questionnaires. All 17 patients who were contacted completed a questionnaire. All the patients were wearing normal shoes, and only one required an orthosis. None used a walking aid. Of the patients in employment, all except the man who had recent surgery for a metastasis in the groin, had returned to their pre-operative occupation. There were two patients who were unhappy with the appearance of their foot/ankle, one was accepting and the remainder were happy.

No pain was experienced in 11 patients, four had occasional pain, and two described constant discomfort, but only one took simple analgesics.

Eight patients described swelling, particularly in hot weather. Of the eight patients who like to participate in sports, six are still able to continue. A further two patients were not able to walk barefoot on the beach or surf since their surgery.

All patients thought that their outcome was preferable to having a below-knee amputation. All were satisfied with their treatment overall, and only one was unsure whether he would have the same management.

\section{Discussion}

Soft-tissue sarcomas of the foot and ankle present a challenge to achieve limb salvage with acceptable functional and oncologic outcomes. Despite what may seem in some cases to be a lengthy programme of treatment, with the potential for complications and a poor outcome, we have shown that good results can be achieved, with preservation of the limb by a combined approach. We had only one failure of treatment, requiring amputation, and this compares well with other published series, which have lower rates of reconstruction by plastic surgery. Colterjohn et $\mathrm{al}^{8}$ also had one failure in 30 patients $(97 \%)$ and Talbert et al, ${ }^{6}$ Jyothirmayi et $\mathrm{al}^{9}$ and Selch et $\mathrm{al}^{7}$ described similar results.

Plastic surgical reconstruction was performed in $60 \%$ of our patients, the majority having radial forearm fasciocutaneous flaps. In a review of 25 cases of foot and ankle reconstruction using this flap, Weinzweig and Davies ${ }^{13}$ had a success rate of $92 \%$ when used for diverse indications, including three tumours. They concluded that this flap meets most of the anatomical requirements for the ideal foot flap. It 
Table II. Surgical details and complications

\begin{tabular}{|c|c|c|c|c|c|c|}
\hline Patient & Location & $\mathrm{NV}^{*}$ structure sacrificed & $\begin{array}{l}\text { Prev } \\
\text { unp }\end{array}$ & nPlastic surgery & $\begin{array}{l}\text { Flap } \\
\text { complications }\end{array}$ & $\begin{array}{l}\text { Other } \\
\text { complications }^{\ddagger}\end{array}$ \\
\hline 1 & Foot - plantar & All contents 1 st $\&$ 2nd interspaces & Yes & Radial forearm flap & None & \\
\hline 2 & Foot - dorsum & All dorsal NV structures & Yes & Radial forearm flap & None & \\
\hline 3 & Ankle-medial & None & Yes & Plantar vascularised & Slow-healing ulcer & \\
\hline 4 & Foot - great toe & NV structures to 3 rd toe & Yes & None & $N / A^{\dagger}$ & \\
\hline 5 & Foot - plantar & None & Yes & Gracilis flap & None & \\
\hline 6 & Ankle - medial & $\begin{array}{l}\text { Dorsalis pedis and deep peroneal } \\
\text { nerve }\end{array}$ & & None & $\mathrm{N} / \mathrm{A}$ & $\begin{array}{l}\text { Wound edge } \\
\text { necrosis, excision } \\
\text { of wound edges }\end{array}$ \\
\hline 7 & Ankle - lateral & Posterior tibial nerve and artery & Yes & None & $\mathrm{N} / \mathrm{A}$ & Radiation burn \\
\hline 8 & Foot - plantar & Medial NV bundle to great toe & Yes & None & $\mathrm{N} / \mathrm{A}$ & $\begin{array}{l}\text { Superficial blister- } \\
\text { ing post RT }\end{array}$ \\
\hline 9 & Ankle - medial & None & Yes & None & $\mathrm{N} / \mathrm{A}$ & \\
\hline 10 & Foot - medial & None & & None & $\mathrm{N} / \mathrm{A}$ & \\
\hline 11 & Foot - medial & All NV structures to 1 st and 2 nd rays & & None & $\mathrm{N} / \mathrm{A}$ & \\
\hline 12 & Foot - hindfoot & Posterior tibial artery & Yes & Radial forarm flap & $\begin{array}{l}\text { Flap infection, } \\
\text { ulcer, declined } \\
\text { amputation }\end{array}$ & \\
\hline 13 & Foot - dorsum & Dorsalis pedis artery & Yes & Radial forearm flap & None & \\
\hline 14 & Foot - plantar & $\begin{array}{l}\text { Digital nerves to index and } \\
\text { middle toes }\end{array}$ & & None & $\mathrm{N} / \mathrm{A}$ & \\
\hline 15 & Foot - plantar & Posterior tibial nerve and artery & & Local rotation flap & None & \\
\hline 16 & Ankle - lateral & $\begin{array}{l}\text { Sural, deep and superficial peroneal } \\
\text { nerves }\end{array}$ & & Gracilis flap & None & \\
\hline 17 & Foot - dorsum & None & Yes & Radial forarm flap & None & \\
\hline 18 & Ankle - lateral & None & Yes & Radial forearm flap & $\begin{array}{l}\text { Persistent non } \\
\text { healing ulcer }\end{array}$ & $\begin{array}{l}\text { CRPS, painful non- } \\
\text { functioning limb. } \\
\text { BKA }\end{array}$ \\
\hline 19 & Foot - medial & None & Yes & Dorsalis pedis flap & $\begin{array}{l}\text { Delayed wound } \\
\text { healing }\end{array}$ & \\
\hline 20 & Ankle - lateral & None & & Latissimus dorsi flap & None & $\begin{array}{l}\text { Small CVA post- } \\
\text { operative, multiple } \\
\text { medical problems }\end{array}$ \\
\hline 21 & Foot - plantar & None & Yes & None & N/A & \\
\hline 22 & Foot - hindfoot & None & & Radial forearm flap & None & \\
\hline 23 & Foot - plantar & NV structures to 5 th ray & & Radial forearm flap & None & \\
\hline 24 & Foot - dorsum & None & Yes & Radial forearm flap & None & $\begin{array}{l}\text { Infective radiation } \\
\text { dermatitis }\end{array}$ \\
\hline 25 & Foot - great toe & $\begin{array}{l}\text { Digital nerves and arteries to } \\
\text { great toe }\end{array}$ & Yes & None & $\mathrm{N} / \mathrm{A}$ & \\
\hline 26 & Ankle - medial & None & & Radial forearm flap & None & \\
\hline 27 & Ankle - medial & Posterior tibial nerve and artery & & None & $\mathrm{N} / \mathrm{A}$ & $\begin{array}{l}\text { Local inflamma- } \\
\text { tion with patchy } \\
\text { skin loss post RT }\end{array}$ \\
\hline
\end{tabular}

facilitates the restoration of normal foot contour by replacing 'like with like', allowing patients to use normal shoes without the need for debulking, and it provides a durable and stable weight-bearing plantar surface when walking. All of our patients were able to return to wearing normal shoes.

Sarcomas of the distal extremity have a better survival than sarcomas located elsewhere. Zeytoonjian et $\mathrm{al}^{1}$ showed an overall death rate from all sarcomas of $26.6 \%$, and from the foot and ankle of $10.3 \%$. That in our series was $14.8 \%$. The reasons for the improved survival include the fact that small lesions in the foot and ankle are often noticed early because they interfere with function. A tumour which is small, noticed early, and in a distal part of the limb, which has a relatively limited blood supply, is less likely to metastasise and cause death. ${ }^{1}$ Given the improved survival of sarcomas in this location, our treatment regimen would seem justified.

An unplanned excision or biopsy had been carried out on 16 patients $(56 \%)$ prior to referral to our unit. This is a relatively common occurrence in soft-tissue sarcomas of the foot and ankle, given that benign lesions outnumber malignant ones by 100 to $1 .{ }^{14}$ Temple et al ${ }^{2}$ observed that $51 \%$ of their foot and ankle tumours had unplanned excisions at other institutions. These patients needed more complicated surgery, had more peri-operative complications, and were more likely to be treated with adjuvant radiotherapy. However, there were no differences in the oncological outcomes. 


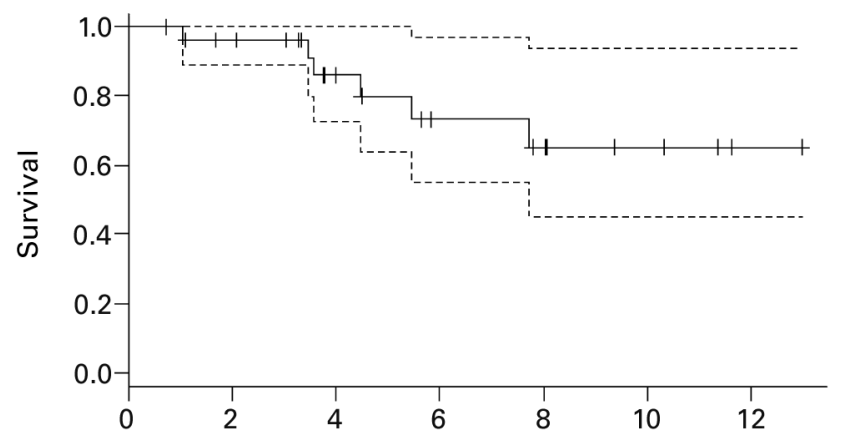

Time (yrs)

Fig. 4

Kaplan-Meier survival showing overall survival.

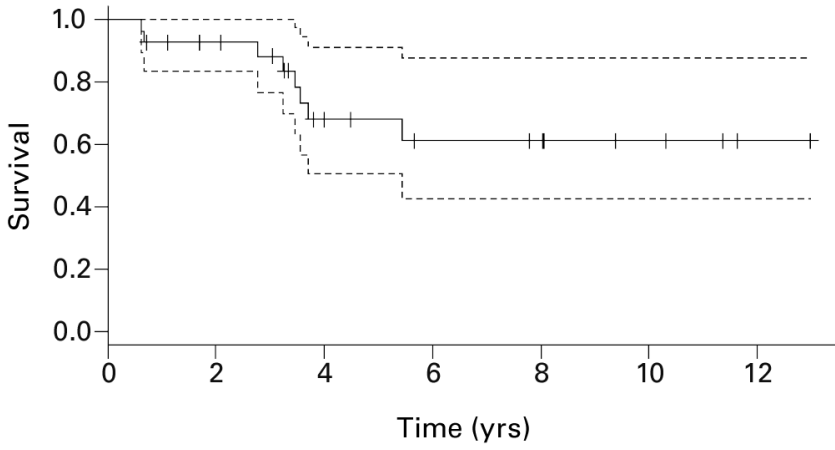

Fig. 5

Kaplan-Meier survival showing disease-specific survival.

The TESS has demonstrated reliability, validity and responsiveness in injury to the lower limb. ${ }^{12}$ The mean overall score in our patients was 89.4 (52.1 to 100$)$, which is comparable with other published series for this location of 88.1. ${ }^{15}$ The questionnaire responses demonstrate a high rate of satisfaction. We have not performed a primary below-knee amputation in the last 12 years. The benefits of time-consuming surgical reconstruction and adjuvant therapies are often questioned, given the excellent functional results that can be obtained with below-knee amputation. Comparisons of the quality of life between limb salvage and amputation for sarcomas of the lower extremity show little difference, ${ }^{16,17}$ but these studies were not specific for the distal part. The presence of a soft-tissue sarcoma in the foot or ankle is not an indication for amputation. Good functional and oncological results can be achieved with a combination of excision of the tumour and, where required, plastic surgical reconstruction and/or adjuvant therapies.

No benefits in any form have been received or will be received from a commercial party related directly or indirectly to the subject of this article.

\section{References}

1. Zeytoonjian T, Mankin HJ, Gebhardt MC, Hornicek FJ. Distal lower extremity sarcomas: frequency of occurrence and patient survival rate. Foot Ankle Int 2004;25:325-30

2. Temple HT, Worman DS, Mnaymneh WA. Unplanned surgical excision of tumours of the foot and ankle. Cancer Control 2001;8:262-8.

3. Lindberg RD, Martin RG, RomsdahI MM, Barkley HT Jr. Conservative surgery and postoperative radiotherapy in 300 adults with soft-tissue sarcomas. Cancer 1981;47:2391-7.

4. Eilber FR, Mirra JJ, Grant TT, Weisenburger T, Morton DL. Is amputation necessary for sarcomas?: a seven-year experience with limb salvage. Ann Surg 1980;192:431-8

5. Suit HD, Russell WO, Martin RG. Management of patients with sarcoma of soft tissue in an extremity. Cancer 1973;31:1247-55.

6. Talbert ML, Zagars GK, Sherman NE, RomsdahI MM. Conservative surgery and radiation therapy for soft tissue sarcoma of the wrist, hand, ankle, and foot. Cancer 1990;66:2482-91.

7. Selch MT, Kopald KH, Ferreiro GA, et al. Limb salvage therapy for soft tissue sarcomas of the foot. Int $J$ Radiat Oncol Biol Phys 1990;19:41-8.

8. Colterjohn NR, Davis AM, O'Sullivan B, et al. Functional outcome in limb-salvage surgery for soft tissue tumours of the foot and ankle. Sarcoma 1997;1:67-74.

9. Jyothirmayi R, Sittampalam Y, Harmer C. Soft tissue sarcoma of the hand or foot: conservative surgery and radiotherapy. Sarcoma 1999;3:17-24.

10. Scully SP, Temple HT, Harrelson JM. Synovial sarcoma of the foot and ankle. Clin Orthop 1999;364:220-6.

11. DeLaney TF, Trofimov AV, Engelsman M, Suit HD. Advanced-technology radiation therapy in the management of bone and soft tissue sarcomas. Cancer Control 2005;12:27-35.

12. Davis AM, Wright JG, Williams JI, et al. Development of a measure of physical function for patients with bone and soft tissue sarcoma. Qual Life Res 1996;5:508-16.

13. Weinzweig N, Davies BW. Foot and ankle reconstruction using the radial forearm flap: a review of 25 cases. Plast Reconstr Surg 1998;102:1999-2005.

14. Fletcher CDM, Krishnan K, Mertens F, eds. Pathology and genetics of tumours of soft tissues and bone. Lyon: IARC Press 2002.

15. Gerrand CH, Wunder JS, Kandel RA, et al. The influence of anatomic location on functional outcome in lower-extremity soft-tissue sarcoma. Ann Surg Oncol 2004;11:476-82.

16. Refaat Y, Gunnoe J, Hornicek FJ, Mankin HJ. Comparison of quality of life after amputation or limb salvage. Clin Orthop 2002;397:298-305.

17. Zahlten-Hinguranage A, Bernd L, Ewerbeck V, Sabo D. Equal quality of life after limb-sparing or ablative surgery for lower extremity sarcomas. $\mathrm{Br} \mathrm{J}$ Cancer 2004:91:1012-14. 